Supporting Information

\title{
Observing Host-Guest Interactions at Molecular Interfaces by Monitoring the Electrochemical Current
}

\author{
Qiushuang Ai, Lunqiang Jin, Zhengjie Gong, and Feng Liang*
}

The State Key Laboratory of Refractories and Metallurgy, School of Chemistry and Chemical Engineering, Wuhan University of Science and Technology, Wuhan 430081, P. R. China.

* Corresponding author: Feng Liang (feng_liang@,whu.edu.cn) 


\section{CONTENTS}

1. Molecules preparation

2. The ${ }^{1} \mathrm{H}$ NMR and ${ }^{13} \mathrm{C}$ NMR spectra of R terminated molecules (Figure S1-S6)

3. $\mathrm{CB}[7]$ capped GNPs characterization (Figure S7)

4. CV measurements (Figure S8)

5. Contact angle of SAMs (Figure S9)

6. I-t measurements (Figure S10-S12)

7. Size effect (Figure S13-S16)

8. Reference 


\section{Molecules preparation}

Molecules were prepared and fully characterized by our lab.

R1 terminated molecule (Fc), $S$-(5-((((ferrocene-1-yl)methyl)(methyl)amino)pentyl) ethanethioate, as a colourless oil. ${ }^{1} \mathrm{H}$ NMR $\left(600 \mathrm{MHz}, \mathrm{CDCl}_{3}\right) \delta 4.11(\mathrm{~d}, \mathrm{~J}=11.7 \mathrm{~Hz}, 2 \mathrm{H}), 4.08(\mathrm{~s}, 7 \mathrm{H}), 3.35(\mathrm{~s}, 2 \mathrm{H}), 2.83(\mathrm{t}, \mathrm{J}=$ $7.3 \mathrm{~Hz}, 2 \mathrm{H}), 2.35-2.26(\mathrm{~m}, 3 \mathrm{H}), 2.26-2.19(\mathrm{~m}, 2 \mathrm{H}), 2.11(\mathrm{~s}, 3 \mathrm{H}), 1.60-1.50(\mathrm{~m}, 2 \mathrm{H}), 1.44(\mathrm{dt}, \mathrm{J}=15.0,7.6$ $\mathrm{Hz}, 2 \mathrm{H}), 1.31(\mathrm{dt}, \mathrm{J}=15.0,7.5 \mathrm{~Hz}, 2 \mathrm{H}) ; 13 \mathrm{C} \mathrm{NMR}\left(150 \mathrm{MHz}, \mathrm{CDCl}_{3}\right) \delta 195.90,82.98,70.17,68.42,67.89$, 57.06, 56.32, 41.73, 30.62, 29.43, 29.05, 26.87, 26.68; HRMS (ESI): $\mathrm{m} / \mathrm{z}$ calcd for $\mathrm{C}_{19} \mathrm{H}_{28} \mathrm{FeNOS}^{+}$ $[\mathrm{M}+\mathrm{H}]^{+}: 374.1236$; found 374.1238 .

R2 terminated molecule (Ad), $S$-(5-((((3r,5r,7r)-adamantan-1-yl)methyl)(methyl)amino)pentyl) ethanethioate, as a colourless oil. ${ }^{1} \mathrm{H}$ NMR $\left(600 \mathrm{MHz}, \mathrm{CDCl}_{3}\right) \delta 2.85(\mathrm{t}, \mathrm{J}=7.3 \mathrm{~Hz}, 2 \mathrm{H}), 2.32-2.25(\mathrm{~m}, 4 \mathrm{H})$, $2.21(\mathrm{~s}, 3 \mathrm{H}), 1.92(\mathrm{~s}, 6 \mathrm{H}), 1.67(\mathrm{~d}, \mathrm{~J}=12.0 \mathrm{~Hz}, 3 \mathrm{H}), 1.61(\mathrm{~d}, \mathrm{~J}=11.7 \mathrm{~Hz}, 3 \mathrm{H}), 1.56(\mathrm{dd}, \mathrm{J}=14.9,7.4 \mathrm{~Hz}, 2 \mathrm{H})$, $1.46(\mathrm{~s}, 6 \mathrm{H}), 1.41(\mathrm{dt}, \mathrm{J}=14.7,7.3 \mathrm{~Hz}, 2 \mathrm{H}), 1.34(\mathrm{dd}, \mathrm{J}=15.0,8.0 \mathrm{~Hz}, 2 \mathrm{H}) ; 13 \mathrm{C} \mathrm{NMR}\left(150 \mathrm{MHz}, \mathrm{CDCl}_{3}\right) \delta$ $195.81,71.21,60.75,46.14,41.20,37.23,34.76,30.57,29.52,29.11,28.53,27.52,26.59 ;$ HRMS (ESI): $\mathrm{m} / \mathrm{z}$ calcd for $\mathrm{C}_{19} \mathrm{H}_{34} \mathrm{NOS}^{+}[\mathrm{M}+\mathrm{H}]^{+}: 324.2356$; found 324.2356 .

R3 terminated molecule (Ph), S-(5-(benzyl(methyl)amino)pentyl) ethanethioate, as a colourless oil. ${ }^{1} \mathrm{H}$ $\operatorname{NMR}\left(600 \mathrm{MHz}, \mathrm{CDCl}_{3}\right) \delta 7.33-7.17(\mathrm{~m}, 5 \mathrm{H}), 3.45(\mathrm{~s}, 2 \mathrm{H}), 2.85(\mathrm{t}, \mathrm{J}=7.3 \mathrm{~Hz}, 2 \mathrm{H}), 2.36-2.32(\mathrm{~m}, 2 \mathrm{H})$, $2.31(\mathrm{~s}, 2 \mathrm{H}), 2.16(\mathrm{~s}, 3 \mathrm{H}), 1.53(\mathrm{ddt}, \mathrm{J}=30.1,15.0,7.5 \mathrm{~Hz}, 4 \mathrm{H}), 1.42-1.31(\mathrm{~m}, 2 \mathrm{H}) ; 13 \mathrm{C} \mathrm{NMR}(150 \mathrm{MHz}$, $\mathrm{CDCl} 3) \delta 195.94,139.22,128.97,128.13,126.82,62.34,57.19,42.20,30.61,29.41,29.07,26.89,26.57$;

HRMS (ESI): $\mathrm{m} / \mathrm{z}$ calcd for $\mathrm{C}_{15} \mathrm{H}_{24} \mathrm{NOS}^{+}[\mathrm{M}+\mathrm{H}]^{+}: 266.1573$; found 266.1572 . 


\section{The ${ }^{1} \mathrm{H}$ NMR and ${ }^{13} \mathrm{C}$ NMR spectra of $\mathrm{R}$ terminated molecules}

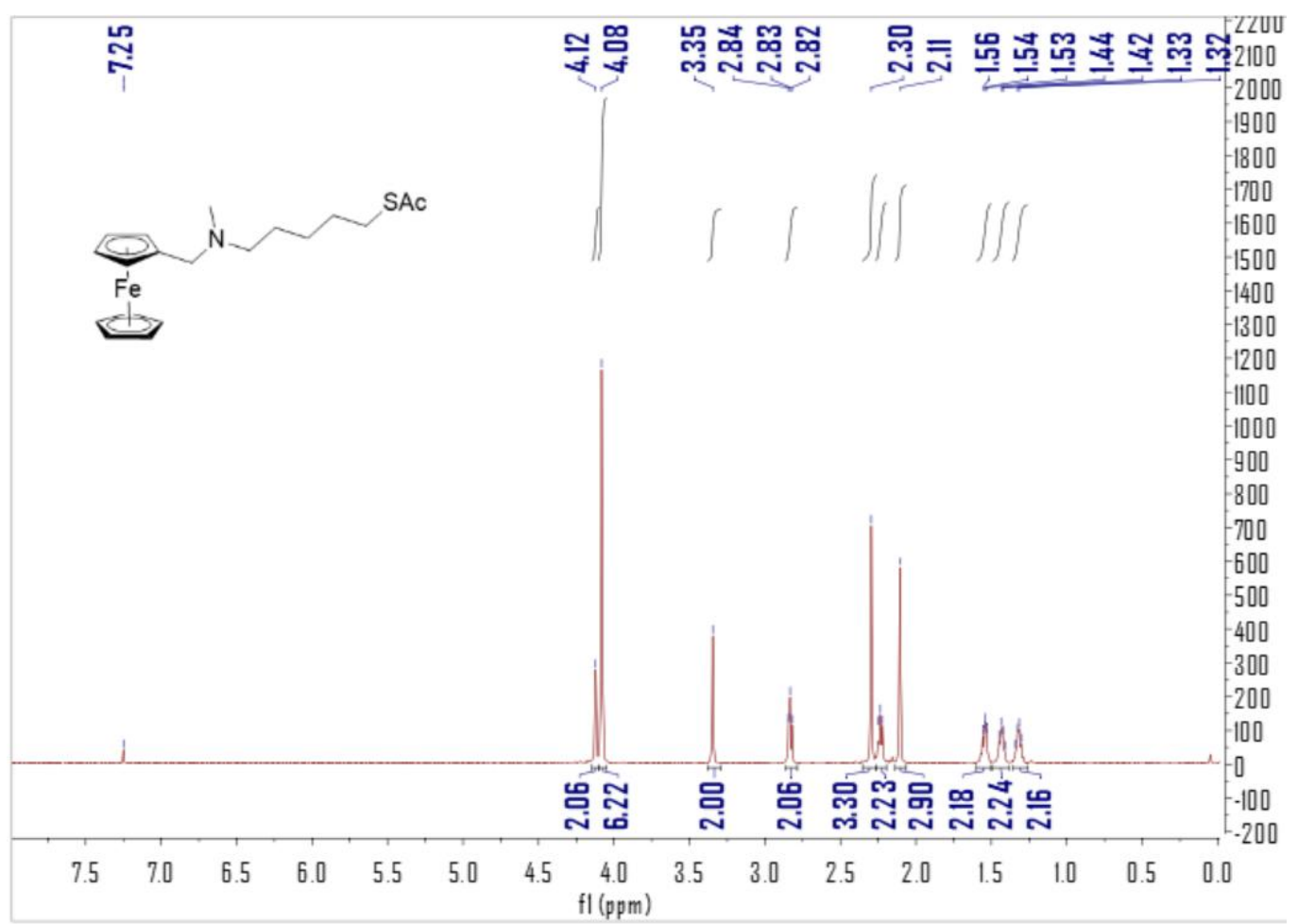

Figure S1. The ${ }^{1} \mathrm{H}$ NMR spectrum $\left(600 \mathrm{MHz}, \mathrm{CDCl}_{3}\right)$ of $\mathrm{R} 1$ terminated molecule.

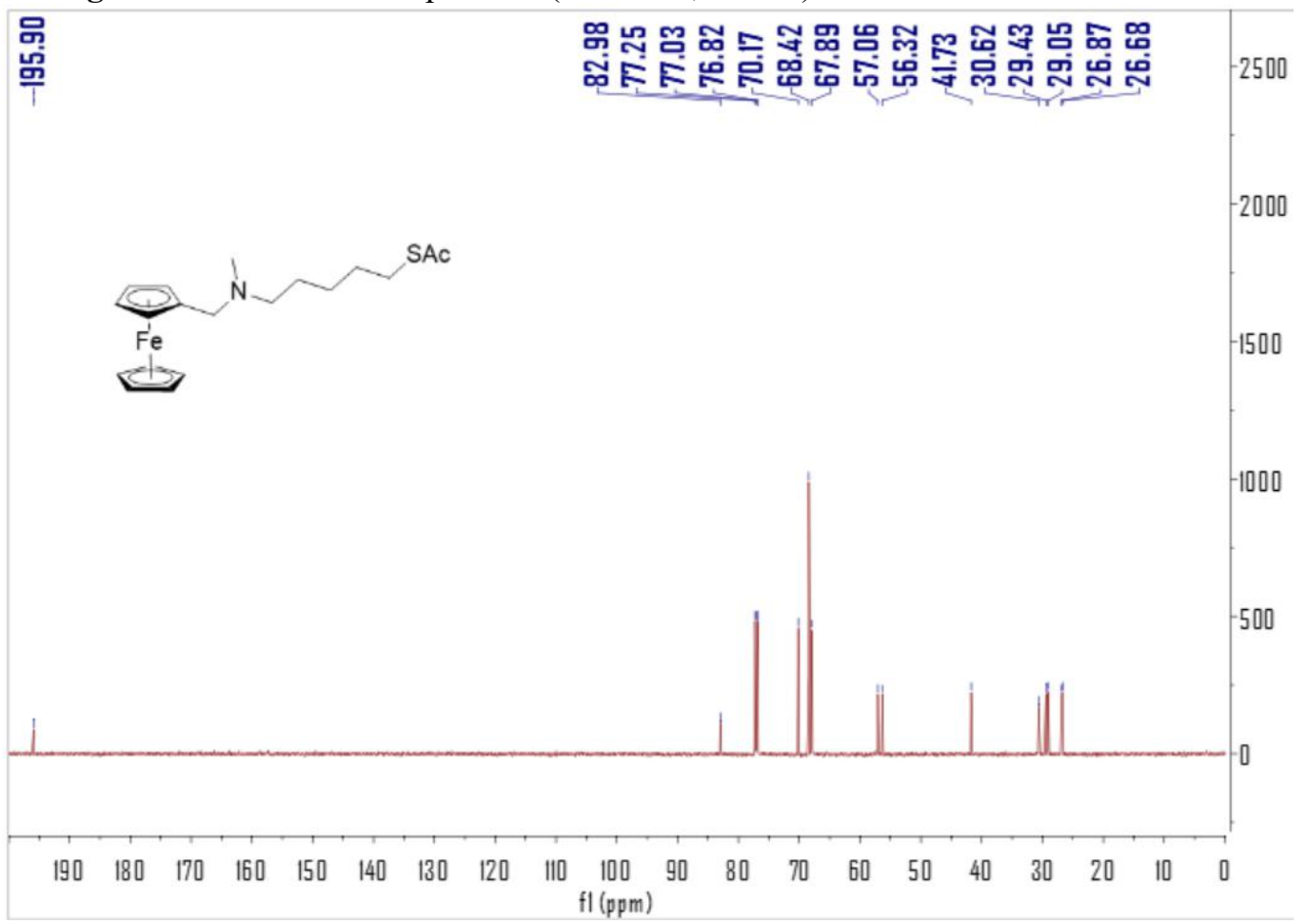

Figure S2. The ${ }^{13} \mathrm{C}$ NMR spectrum $\left(150 \mathrm{MHz}, \mathrm{CDCl}_{3}\right)$ of $\mathrm{R} 1$ terminated molecule. 


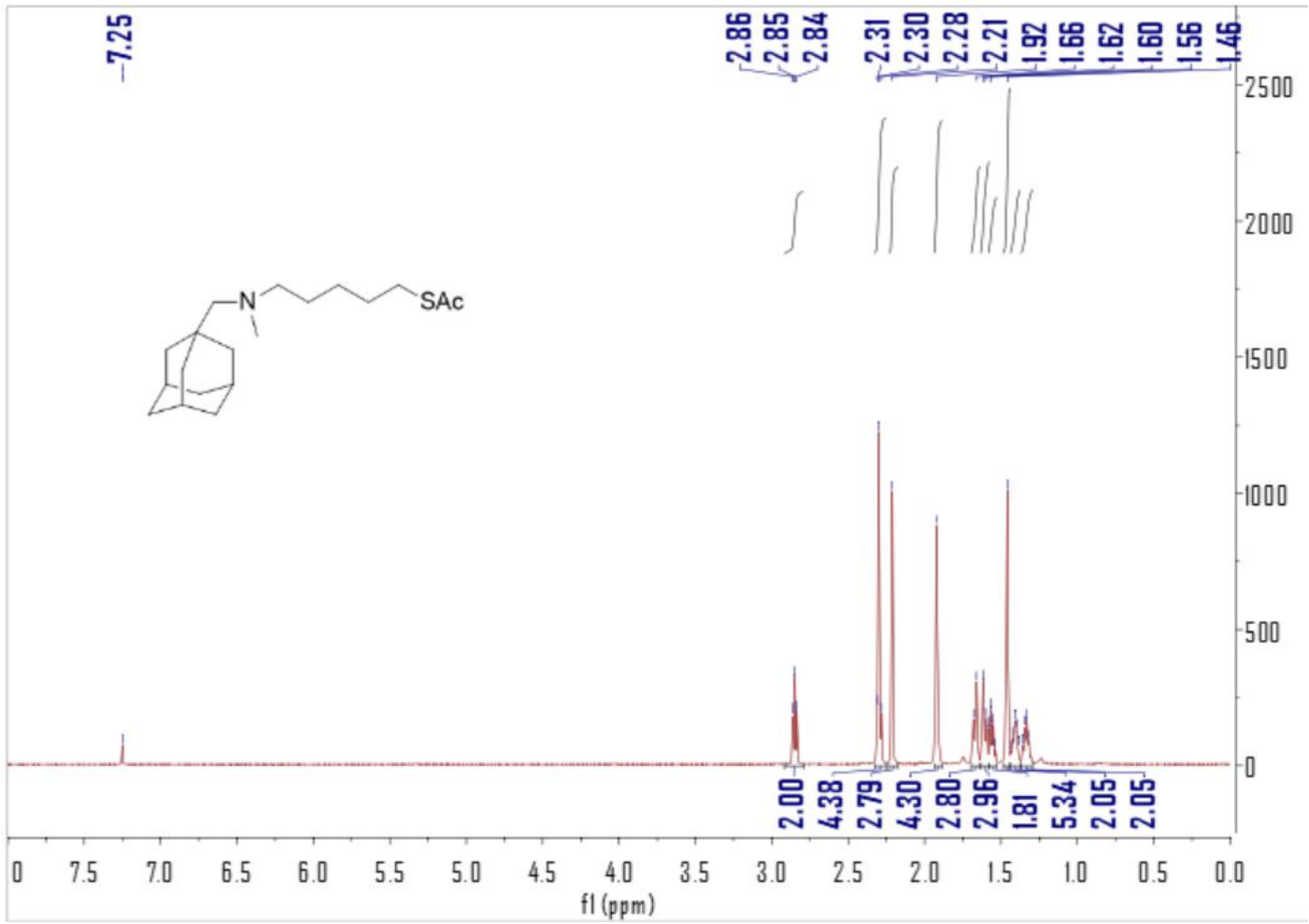

Figure S3. The ${ }^{1} \mathrm{H}$ NMR spectrum $\left(600 \mathrm{MHz}, \mathrm{CDCl}_{3}\right)$ of $\mathrm{R} 2$ terminated molecule.

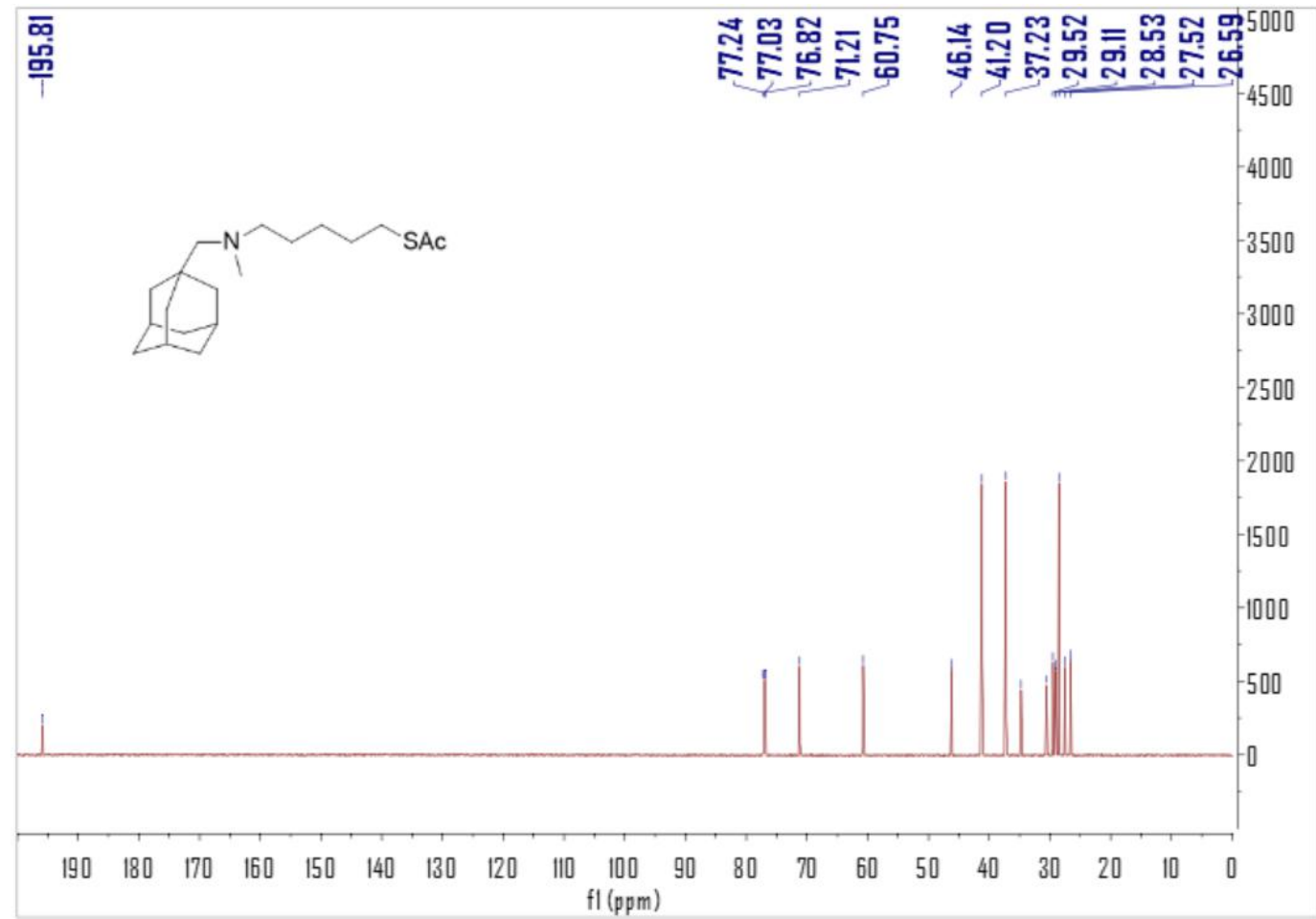

Figure S4. The ${ }^{13} \mathrm{C}$ NMR spectrum $\left(150 \mathrm{MHz}, \mathrm{CDCl}_{3}\right)$ of $\mathrm{R} 2$ terminated molecule. 


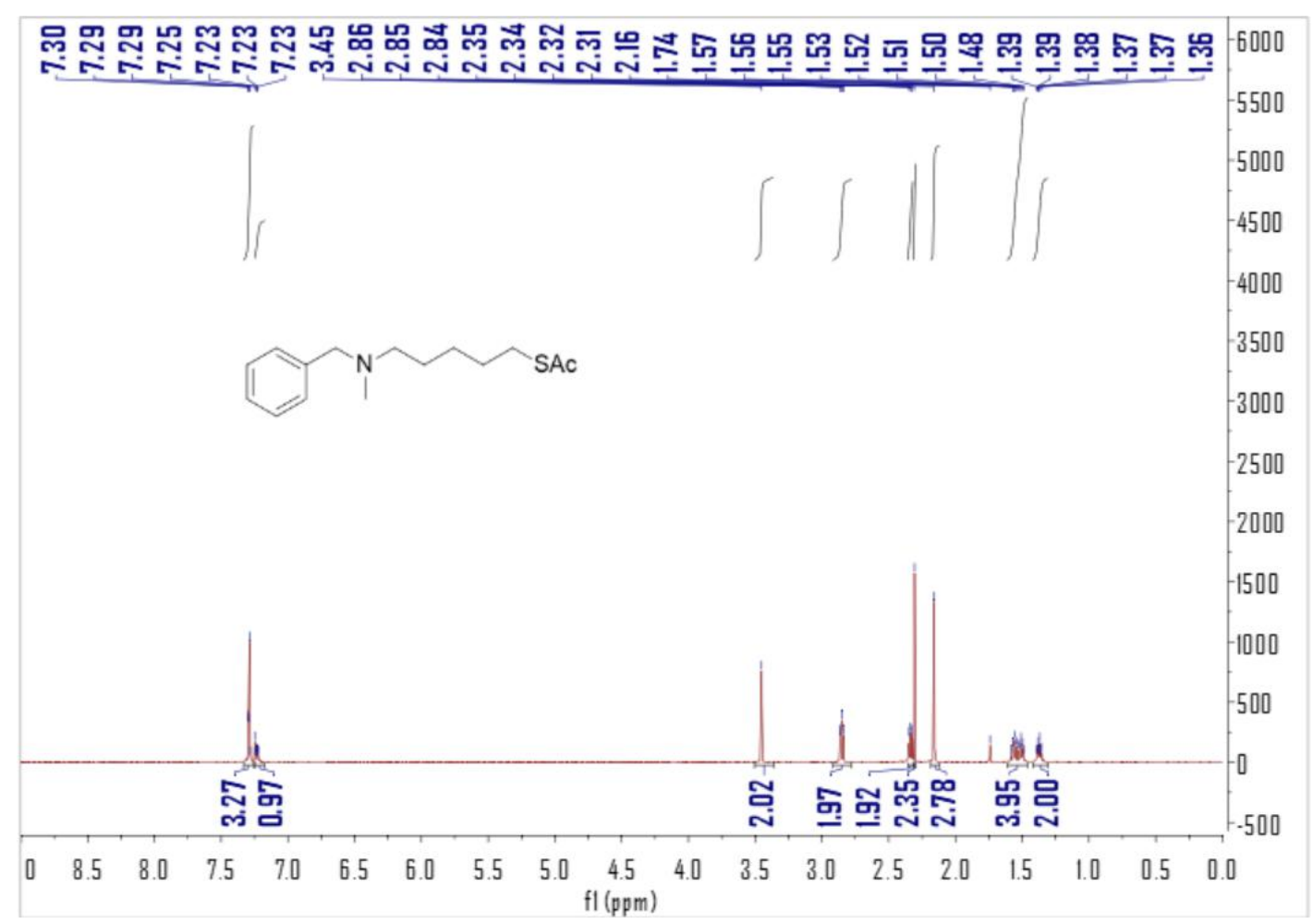

Figure S5. The ${ }^{1} \mathrm{H}$ NMR spectrum $\left(600 \mathrm{MHz}, \mathrm{CDCl}_{3}\right)$ of $\mathrm{R} 3$ terminated molecule.

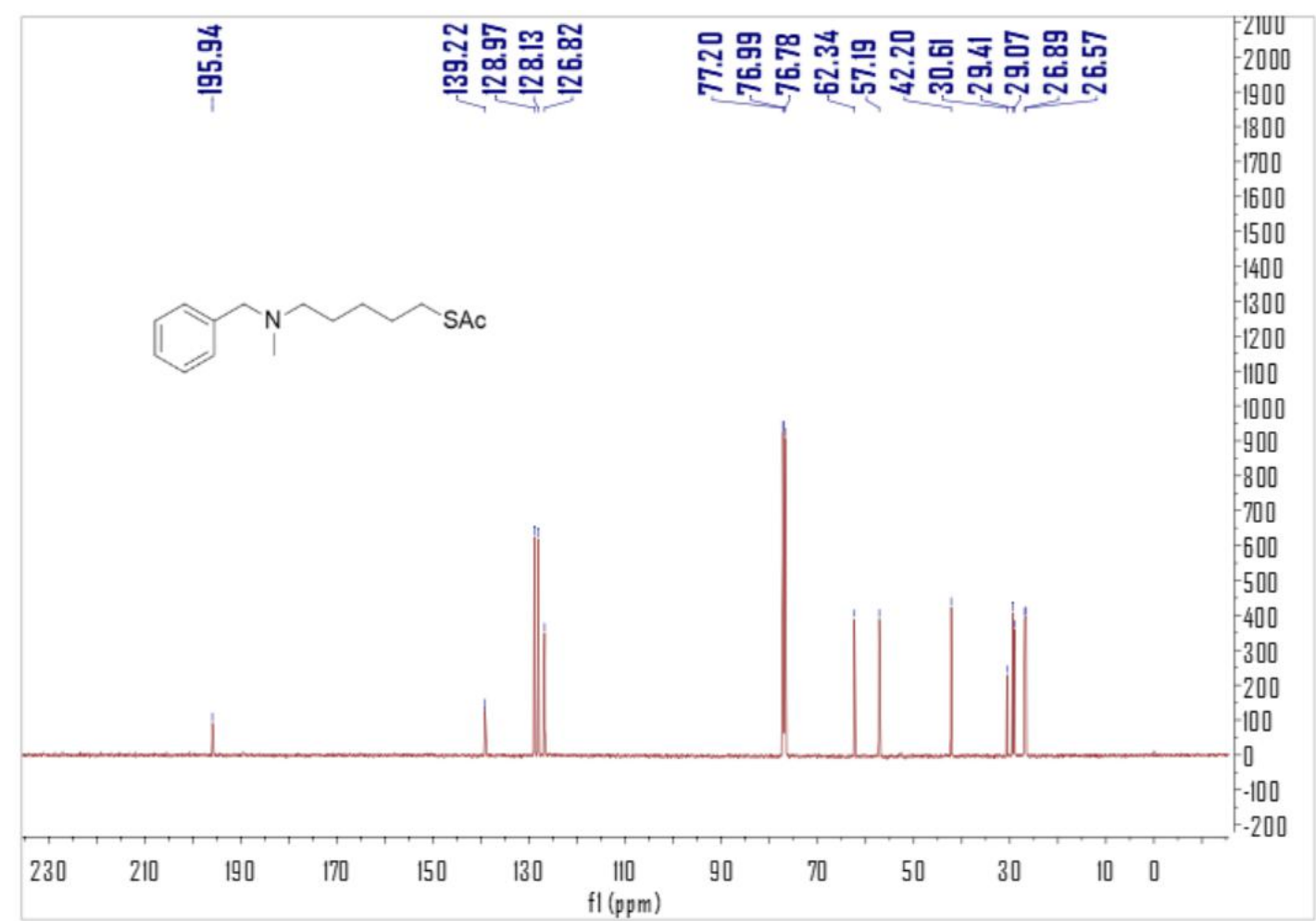

Figure S6. The ${ }^{13} \mathrm{C}$ NMR spectrum $\left(150 \mathrm{MHz}, \mathrm{CDCl}_{3}\right)$ of $\mathrm{R} 3$ terminated molecule. 


\section{3. $\mathrm{CB}[7]$ capped GNPs characterization}

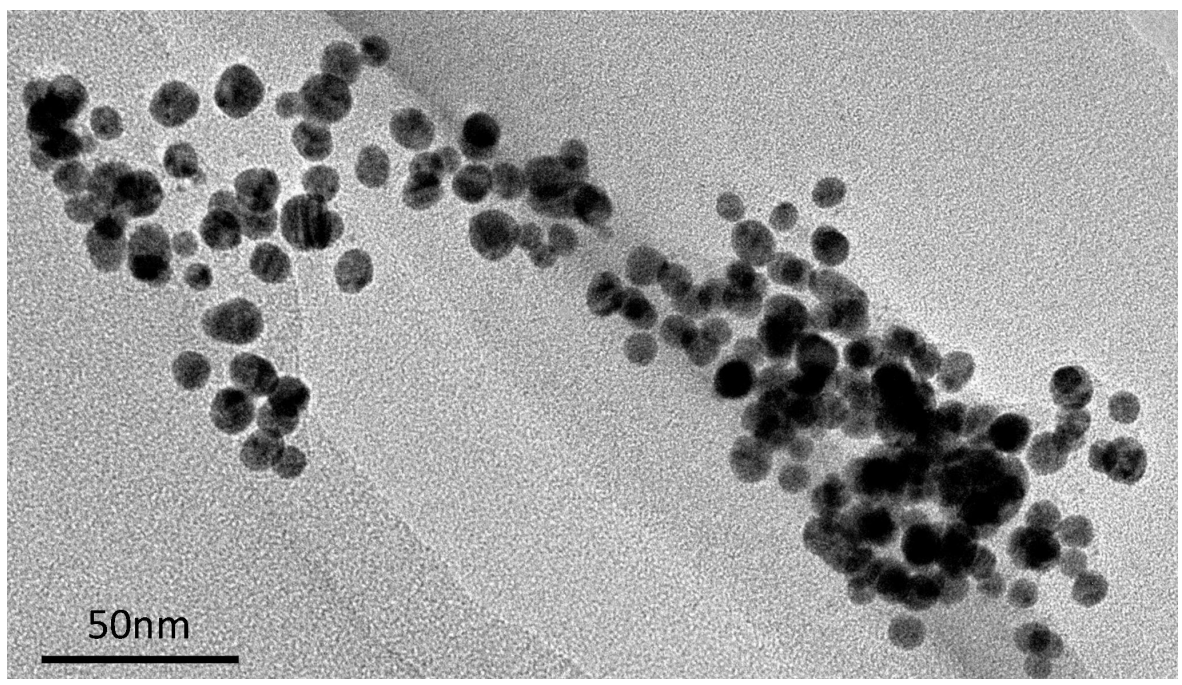

Figure S7. TEM image of CB[7] capped GNPs.

\section{CV measurements}
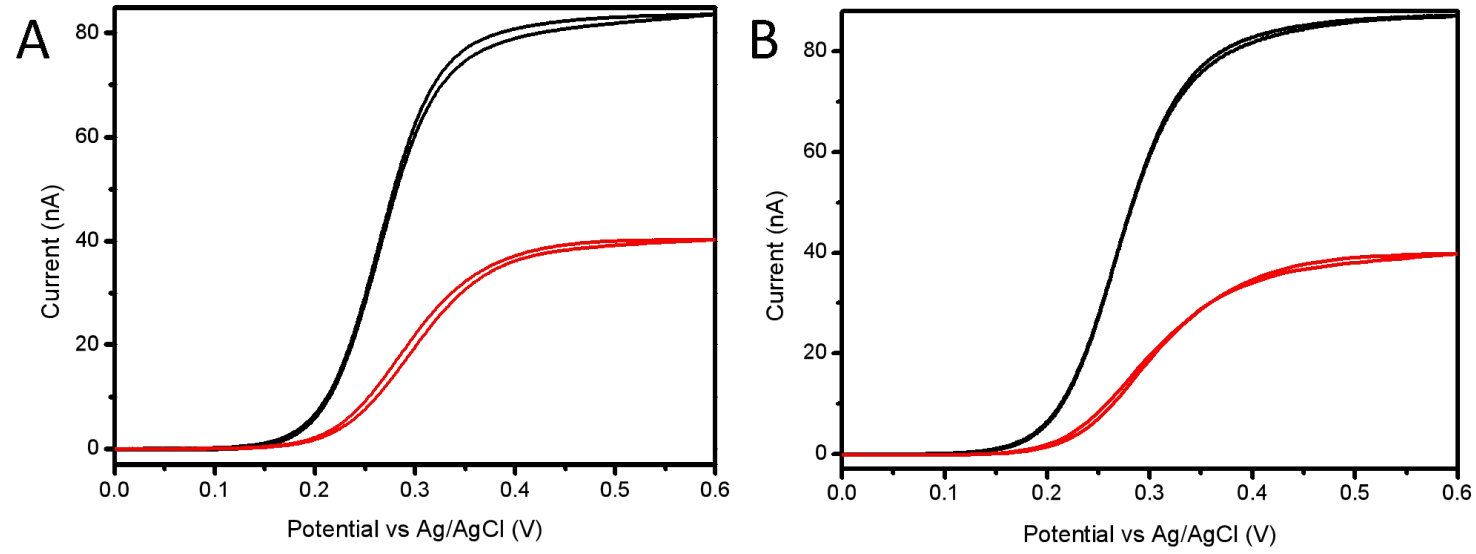

Figure S8. CVs of GNEs before (black) and after (red) modification with R2 (A), R3 (B) terminated molecule. 


\section{Contact angle of SAMs}
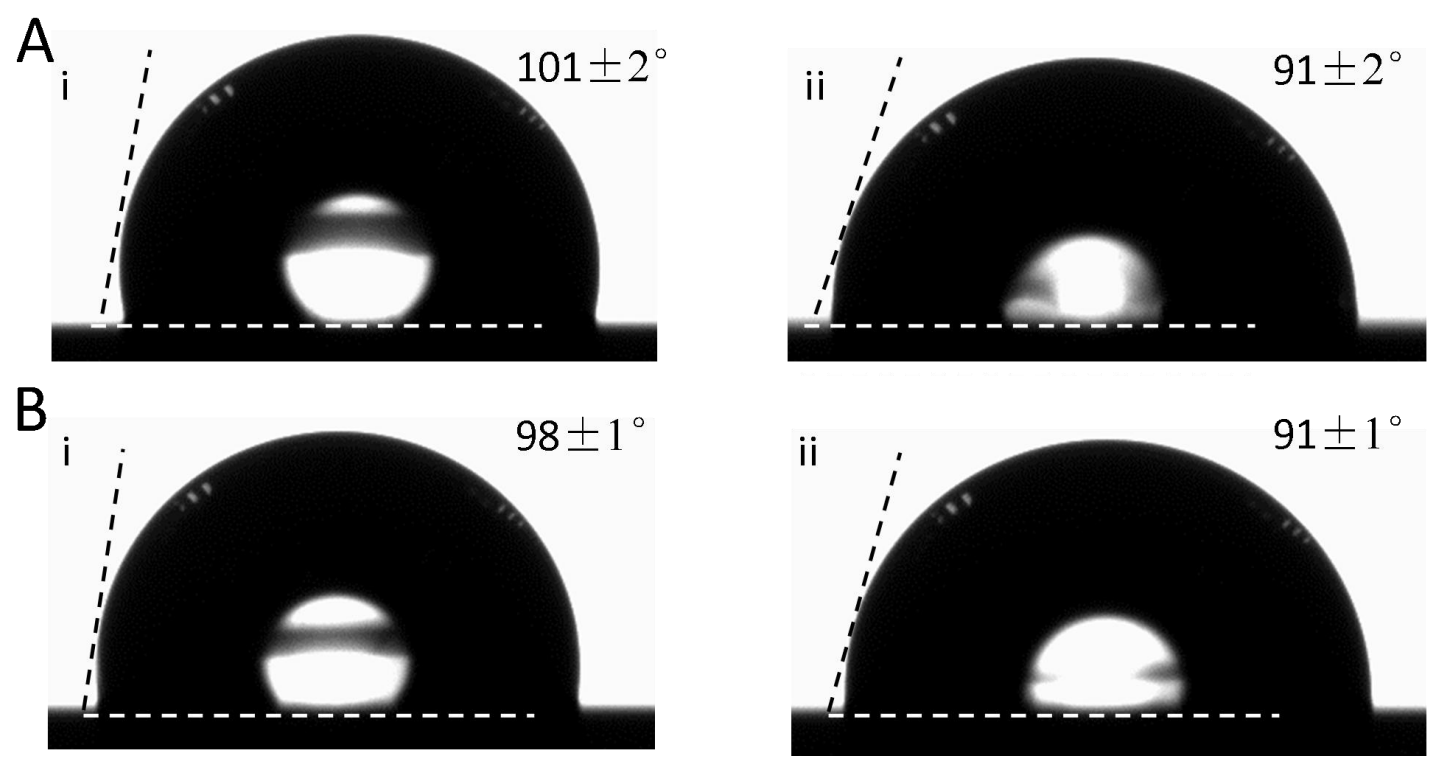

Figure S9. Contact angles of water droplets on gold planar electrode (GPE) modified with terminate group and R2 (A), R3 (B), before (i) and after (ii) immersion with CB[7] capped GNPs.

\section{I-t measurements}
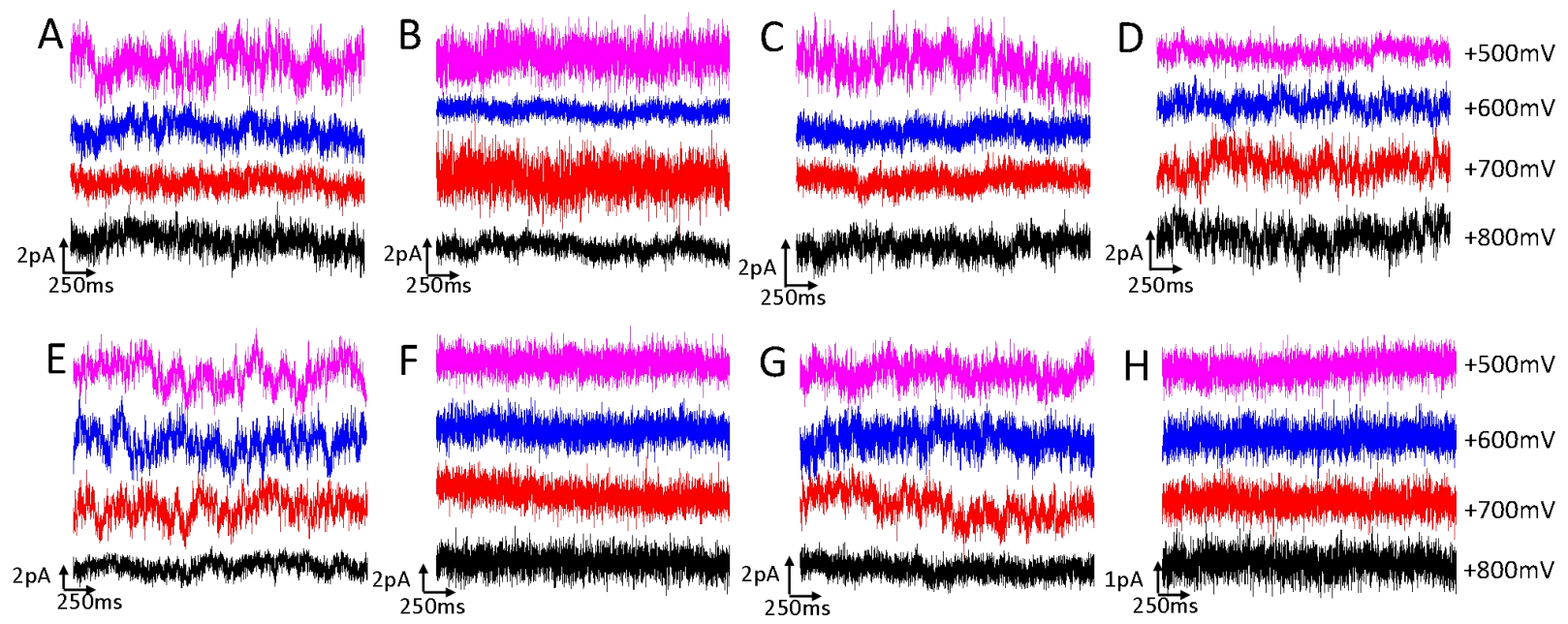

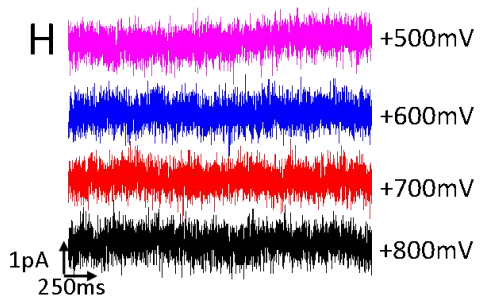

Figure S10. I-t traces of bare GNE (A) and GNEs modified with terminate group R3 (B, F), R1 (C, G), R2 (D, $\mathrm{H})$ with the presence (A, B, C, D) and absence (E, F, G, H) of GNPs in electrolyte solution under different positive bias. 


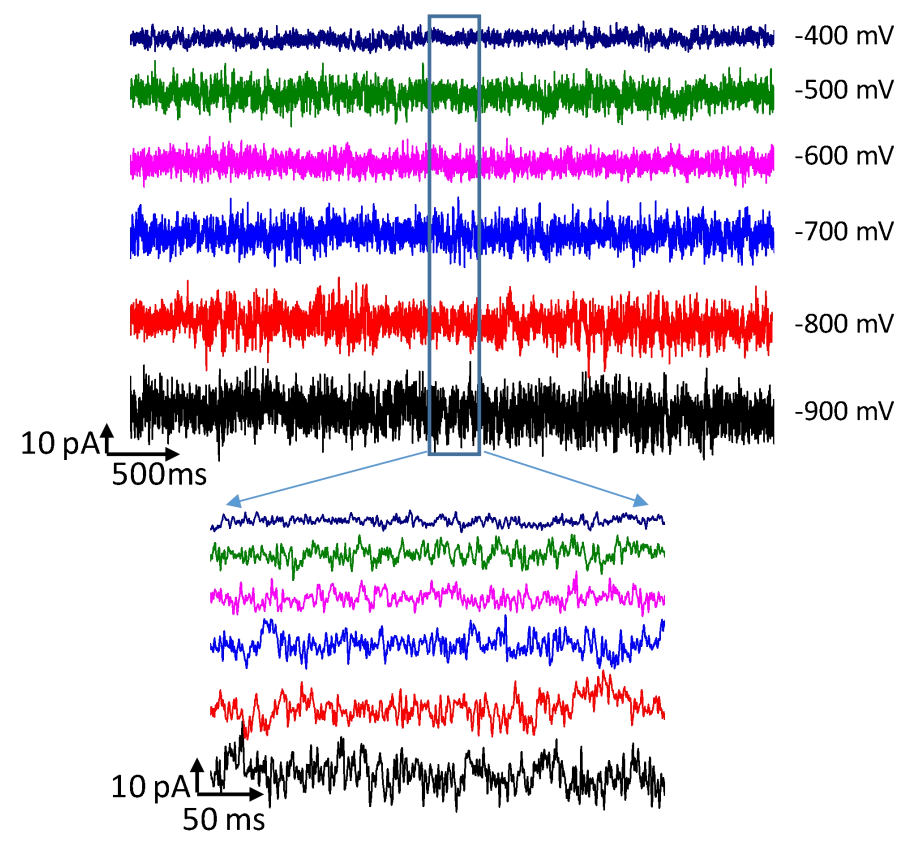

Figure S11. I-t traces of bare GNE with the absence of GNPs in electrolyte solution under different negative bias.
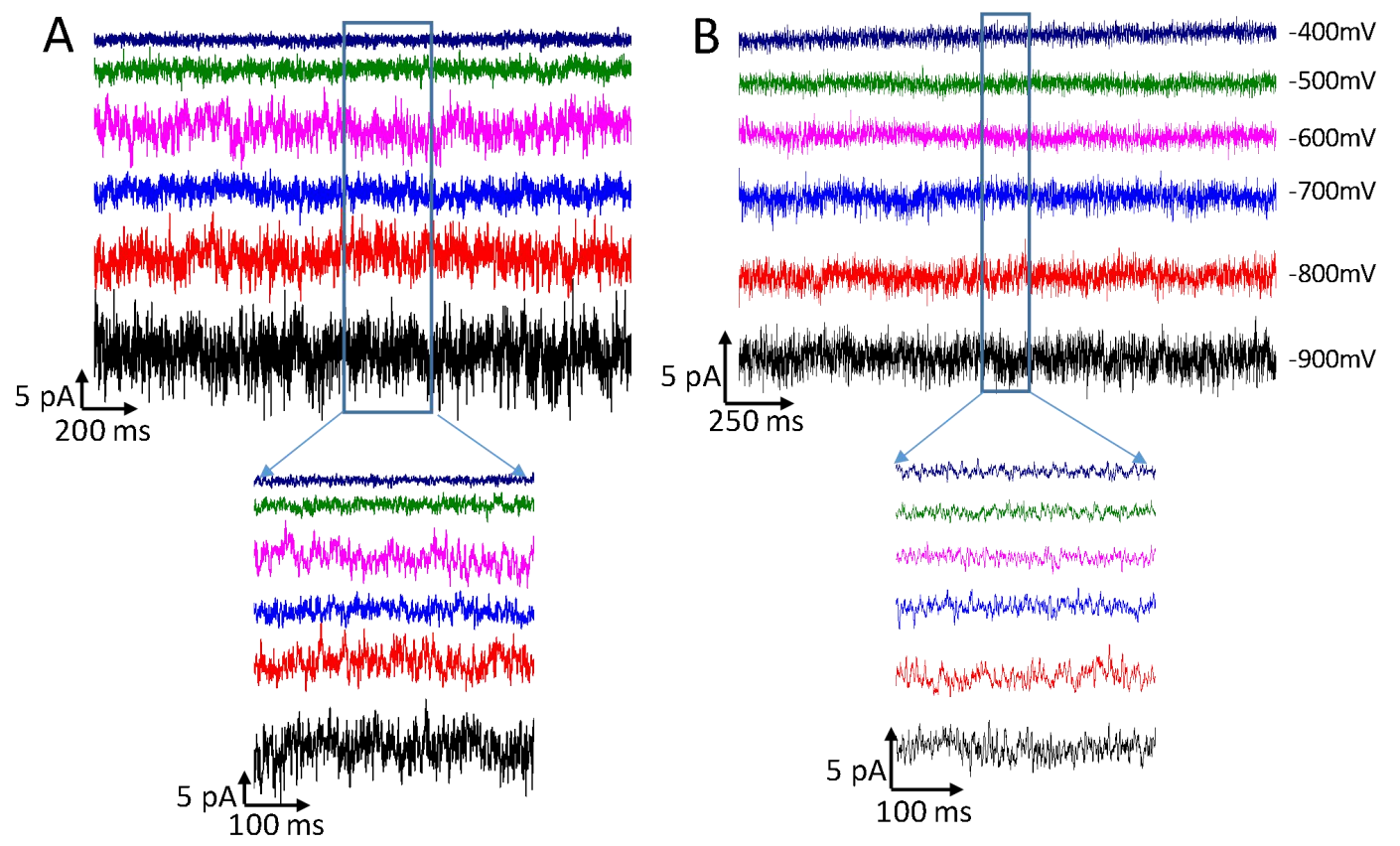

Figure S12. I-t traces of GNEs modified with R2 (A) and R3 (B) terminated molecules with the absence of GNPs in electrolyte solution under different negative bias. 


\section{S7. Size effect}

The diffusion-limited current $\mathrm{i}_{\mathrm{d}}$ is calculated using equation $\mathrm{S} 1,{ }^{1}$

$$
i_{d}=m F D C \sqrt{2 \pi A_{e f f}}
$$

Where $A_{\text {eff }}$ is the exposed area, $\mathrm{m}$ is a geometry factor, $\mathrm{F}$ is the Faraday constant $(96485 \mathrm{C} / \mathrm{mol}), \mathrm{D}$ and $\mathrm{C}$ is the diffusion constant $\left(7.4 \times 10^{-6} \mathrm{~cm}^{2} / \mathrm{s}\right)$ and bulk concentration of Ferrocyanide ions, respectively. The geometry factor $\mathrm{m}=1$ if the electrode is hemispherical, we used $\mathrm{m}=1$ for the calculation.

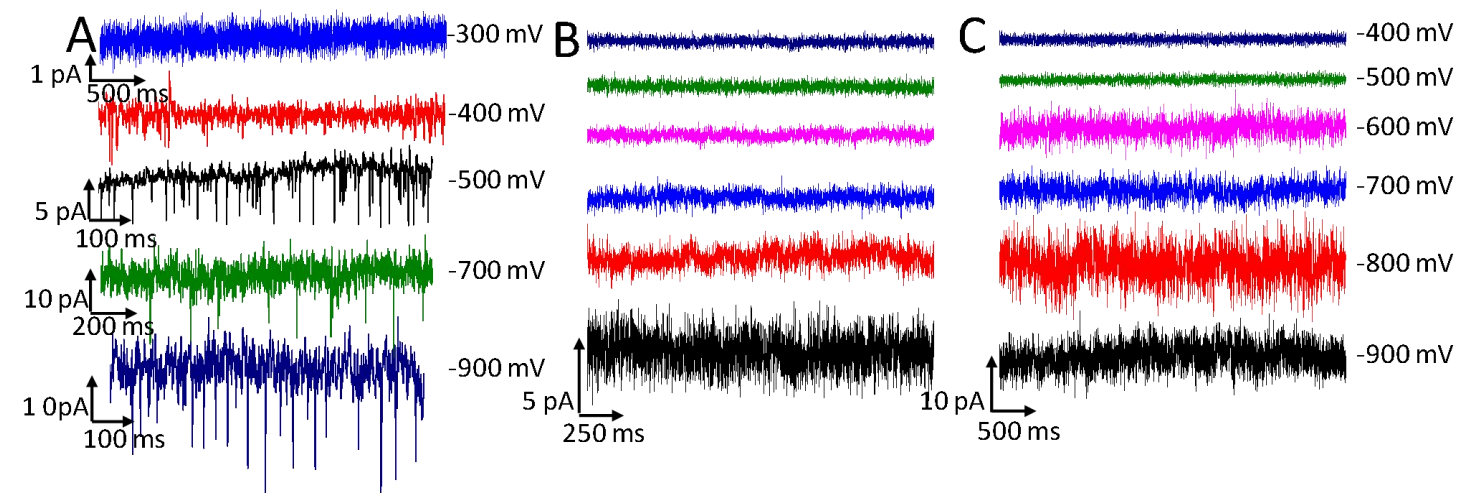

Figure S13. I-t traces of GNEs modified with terminate group R1 (A), R2 (B), R3 (C) molecule with the absence of GNPs in electrolyte solution under different negative bias.

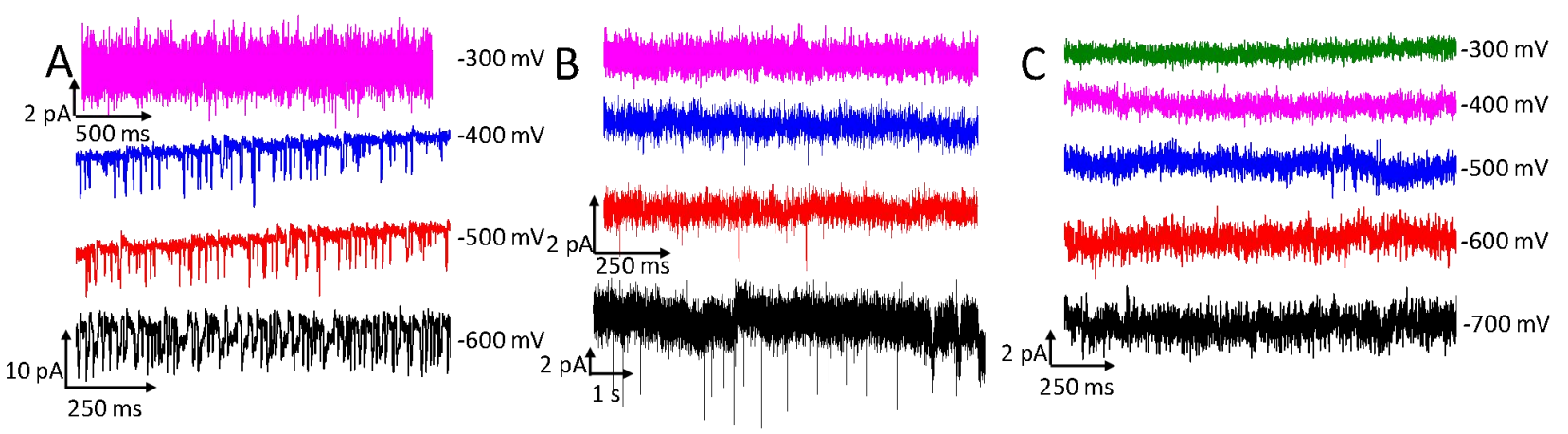

Figure S14. I-t traces of gold electrodes modified with R1 (A), R2 (B) and R3 (C) terminated molecule with the absence of GNPs in electrolyte solution under different negative bias. Here the size of the electrode (A), (B) and (C) was 87.5, 190 and $133 \mu m^{2}$, respectively. 


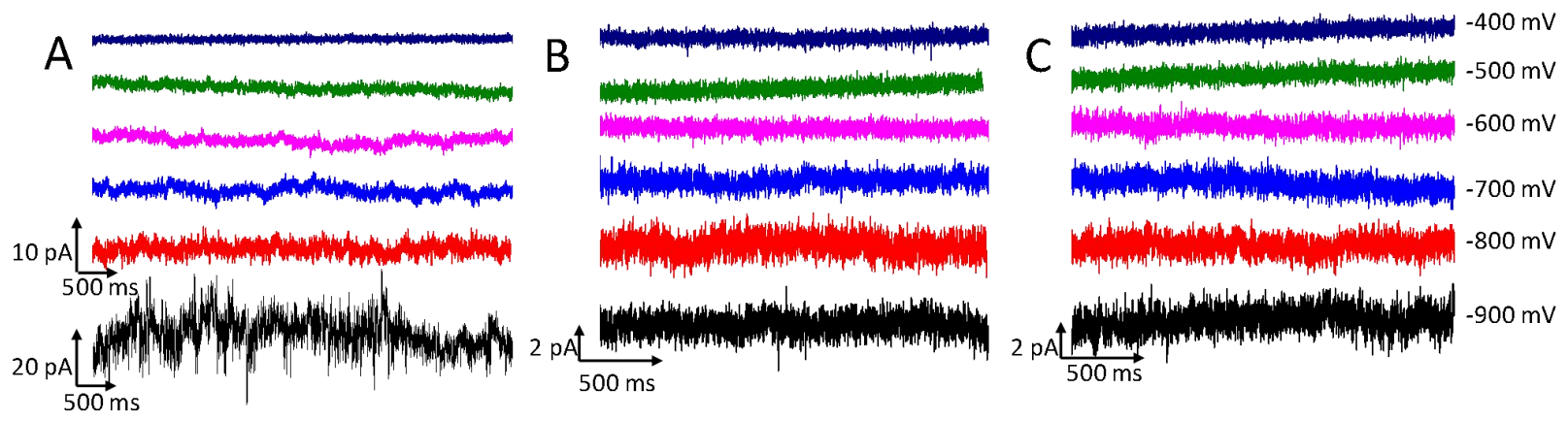

Figure S15. I-t traces of GNEs modified with R1 (A), R2 (B) and R3 (C) terminated molecule with the absence of GNPs in electrolyte solution under different negative bias. Here the size of GNE(A), (B) and R3 (C) was $1.65,3.12$ and $4.32 \mu m^{2}$, respectively.
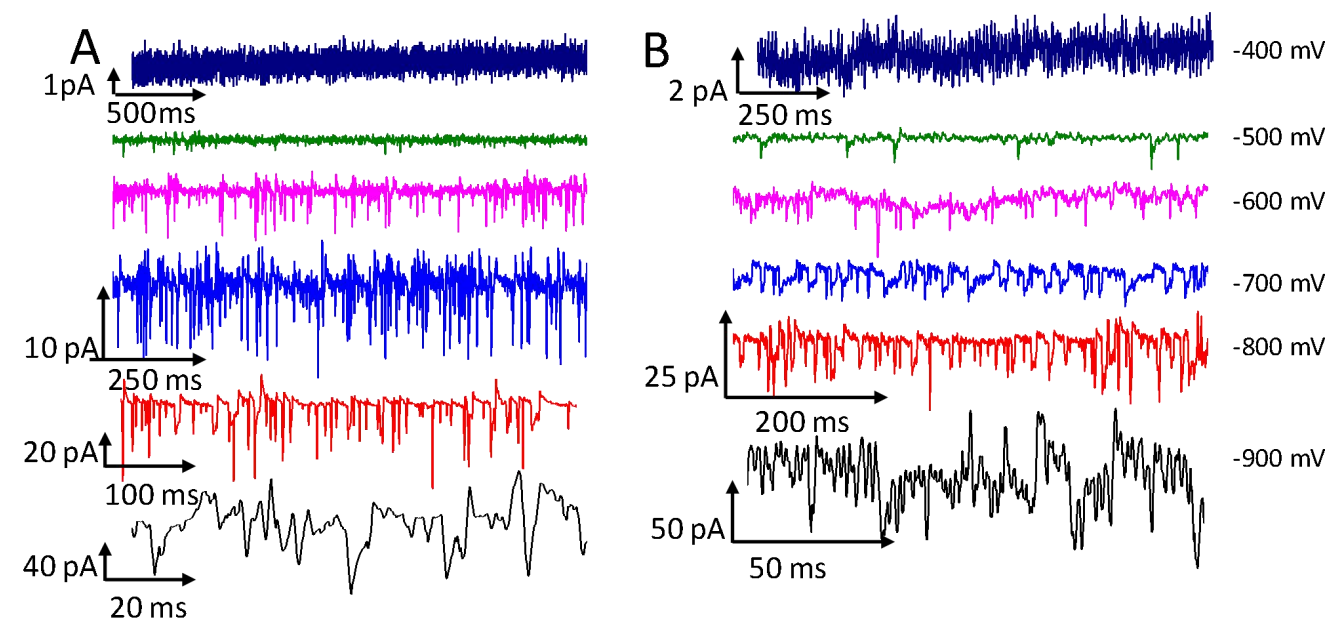

Figure S16. I-t traces of GNEs modified with R1 terminated molecule with the absence of GNPs in electrolyte solution under different negative bias. Here the size of GNE (A) and (B) was 8.33 and $6.13 \mu \mathrm{m}^{2}$, respectively.

\section{Reference}

(1) Kissinger, P.; Heineman, W. R. Modern Techniques in Electroanalysis. CRC press, 1996. 